\title{
Impact of dexamethasone use to prevent from severe COVID-19-induced acute kidney injury
}

Arthur Orieux ${ }^{1 *} \mathbb{0}$, Pierre Khan ${ }^{1}$, Renaud Prevel ${ }^{1}$, Didier Gruson ${ }^{1,2}$, Sébastien Rubin ${ }^{3,4}$ and Alexandre Boyer ${ }^{1,2}$

Keywords: Acute kidney injury, COVID-19, Dexamethasone, Intensive care unit

\section{To the editor}

Since the first wave of COVID-19, the management of patients with severe COVID-19 in intensive care unit (ICU) has changed with the widespread use of dexamethasone (DXM) in severe patients [1]. Indeed, RECOVERY trial [2] showed a decrease in both mortality at day 28 and the number of patients who received renal replacement therapy (RRT) with DXM. We have previously reported a higher than usual incidence of acute kidney injury (AKI) $(80 \%)$ in severe COVID-19 patients treated in ICU [3]. Like lung injury, specific SARS-CoV-2 inflammatory process was previously suggested in AKI pathogenesis $[4,5]$ and is susceptible to be improved by DXM. Besides, in another report, we recently described a $15 \%$ incidence of chronic kidney disease (CKD) at 3 months after COVID19-induced AKI [6], all of these patients developing acute kidney disease (AKD) before CKD. The aim of this report was to assess the independent clinical effect of DXM on the prevention of severe COVID-19-induced AKI.

We carried out a prospective study in the medical ICU of the University Hospital of Bordeaux (France) from March 17, 2020, to December 20, 2020. All patients

*Correspondence: arthur.orieux@chu-bordeaux.fr

${ }^{1}$ Service de Médecine Intensive Réanimation, Hôpital Pellegrin, Place Amélie Raba Léon, CHU de Bordeaux, 33000 Bordeaux, France

Full list of author information is available at the end of the article admitted for a severe COVID-19 were included. DXM was exclusively used during the second wave starting in Bordeaux (France) on August 6 at $6 \mathrm{mg}$ per day for 10 days at ICU admission. Patients who presented AKI at ICU admission were excluded from the analysis.

\section{Patients characteristics (Table 1)}

From March 17, 2020, 126 patients were admitted in our unit, 26/126 patients (21\%) were excluded because of AKI at ICU admission (5 and 21 patients, in first and second waves, respectively). DXM was used in all patients in the second wave and in none of the first wave. In the 100 patients included, median age was $63 \pm 11$ years, $59 / 100(59 \%)$ had hypertension, 10/100 (10\%) suffered from CKD and 48/100 (48\%) required mechanical ventilation (MV) in the first $24 \mathrm{~h}$. In the study population, 56/100 (56\%) patients developed AKI: 39/52 (75\%) and $17 / 48(35 \%)$ patients $(p<0.001)$, in the first and second waves, respectively. AKD was observed in 24/100 (24\%) of patients: $14 / 52(27 \%)$ patients in the first wave and $10 / 48(21 \%)$ in the second wave $(p=0.49)$.

In univariate analysis, the use of DXM $(\mathrm{OR}=0.18[0.07-$ $0.42])$, hypertension $(\mathrm{OR}=2.31[1.03-5.29])$, SAPSII $(\mathrm{OR}=1.04$ [1.01-1.07]), MV $(\mathrm{OR}=8.92$ [3.65-23.66] $)$ and intravenous fluid therapy $(\mathrm{OR}=1.67$ [1.20-2.47]) were significantly associated with AKI. In multivariate analysis, MV $(\mathrm{OR}=5.02[1.68-15.78])$ and DXM use $(\mathrm{OR}=0.31[0.09-0.99])$ remained significantly associated with AKI. original author(s) and the source, provide a link to the Creative Commons licence, and indicate if changes were made. The images or other third party material in this article are included in the article's Creative Commons licence, unless indicated otherwise in a credit line to the material. If material is not included in the article's Creative Commons licence and your intended use is not permitted by statutory regulation or exceeds the permitted use, you will need to obtain permission directly from the copyright holder. To view a copy of this licence, visit http://creativecommons.org/licenses/by/4.0/. The Creative Commons Public Domain Dedication waiver (http://creativeco mmons.org/publicdomain/zero/1.0/) applies to the data made available in this article, unless otherwise stated in a credit line to the data. 


\section{Risk factors for AKI (Table 2)}

\section{Risk factors for AKD}

In univariate analysis, prior CKD $(\mathrm{OR}=13.8$ [3.1497.44]), chronic respiratory disease $(\mathrm{OR}=5.16$ [1.5419.19]), immunosuppression $(\mathrm{OR}=7.67 \quad[1.60-55.75])$ were significantly associated with AKD. In multivariate analysis, only prior CKD $(\mathrm{OR}=17.73[2.91-108.08])$ was significantly associated with AKD (DXM use, OR $=1.10$ [0.32-3.81]).

Table 1 Comparison of baseline characteristics and outcomes

\begin{tabular}{|c|c|c|c|c|}
\hline & $\begin{array}{l}\text { Total } \\
n=100\end{array}$ & $\begin{array}{l}\text { First wave } \\
n=52\end{array}$ & $\begin{array}{l}\text { Second wave } \\
n=48\end{array}$ & $p$-value \\
\hline \multicolumn{5}{|l|}{ Baseline characteristics } \\
\hline Males, No. (\%) & $76(76)$ & $38(73)$ & $38(79)$ & 0.49 \\
\hline Age (years), mean (SD) & $63 \pm 11$ & $61 \pm 12$ & $66 \pm 10$ & 0.009 \\
\hline BMI, mean (SD) & $30 \pm 5$ & $31 \pm 4$ & $30 \pm 5$ & 0.20 \\
\hline CKD, No. (\%) & $10(10)$ & $4(8)$ & $6(12)$ & 0.51 \\
\hline Hypertension, No. (\%) & $59(59)$ & $30(58)$ & $29(60)$ & 0.84 \\
\hline Diabetes, No. (\%) & $33(33)$ & $15(29)$ & $18(37)$ & 0.40 \\
\hline Ischemic cardiopathy, No. (\%) & $13(13)$ & $4(8)$ & $9(19)$ & 0.14 \\
\hline Chronic respiratory disease, No. (\%) & $17(17)$ & $7(13)$ & $10(21)$ & 0.43 \\
\hline Immunosuppression, No. (\%) & $9(9)$ & $4(8)$ & $5(10)$ & 0.73 \\
\hline RASi exposure, No. (\%) & $35(35)$ & $18(35)$ & $17(36)$ & 1 \\
\hline Time between first symptoms and ICU admission (days), mean (SD) & $8 \pm 4$ & $8 \pm 4$ & $8 \pm 3$ & 0.74 \\
\hline Time between first symptoms and hospital admission (days), mean (SD) & $7 \pm 3$ & $7 \pm 3$ & $6 \pm 4$ & 0.49 \\
\hline Time between hospital admission and ICU admission (days), mean (SD) & $1 \pm 2$ & $1 \pm 2$ & $2 \pm 3$ & 0.31 \\
\hline \multicolumn{5}{|l|}{ In the first $24 \mathrm{~h}$ of ICU hospitalization (before AKI development) } \\
\hline SAPS II, median [IQR] & $40[30-52]$ & $40[25-60]$ & $40[33-46]$ & 0.65 \\
\hline Catecholamine use, No. (\%) & $9(9)$ & $8(15)$ & $1(2)$ & 0.03 \\
\hline Mechanical ventilation, No. (\%) & $48(48)$ & $39(75)$ & $9(19)$ & $<0.001$ \\
\hline Worst $\mathrm{PaO}_{2} / \mathrm{FiO}_{2}$ ratio, median [IQR] & $146[98-192]$ & $146[89-205]$ & $146[116-181]$ & 0.76 \\
\hline Intravenous fluid therapy $(\mathrm{L})$, median $[\mathrm{IQR}]$ & $2.36[1.62-3.15]$ & $2.77[2.13-3.63]$ & $1.94[1.42-2.70]$ & 0.0023 \\
\hline Dexamethasone use, No. (\%) & $48(48)$ & $0(0)$ & $48(100)$ & 1 \\
\hline \multicolumn{5}{|l|}{ Main outcomes } \\
\hline ICU mortality, No. (\%) & $19(19)$ & $7(13)$ & $12(25)$ & 0.20 \\
\hline ICU length (days), median [IQR] & $12[6-25]$ & $13[7-27]$ & $11[5-22]$ & 0.26 \\
\hline Hospitalization length (days), median [IQR] & $26[14-39]$ & $27[17-45]$ & $23[13-30]$ & 0.04 \\
\hline Mortality at D28, No. (\%) & $21(21)$ & $9(17)$ & $12(25)$ & 0.46 \\
\hline \multicolumn{5}{|l|}{ Renal outcomes } \\
\hline AKI, No. (\%) & $56(56)$ & $39(75)$ & $17(35)$ & $<0.001$ \\
\hline AKI stage & & & & 0.24 \\
\hline KDIGO 1, No. (\%) & $19(34)$ & $13(33)$ & $6(35)$ & \\
\hline KDIGO 2, No. (\%) & $18(32)$ & $15(38)$ & $3(18)$ & \\
\hline KDIGO 3, No. (\%) & $19(34)$ & $11(28)$ & $8(47)$ & \\
\hline Renal replacement therapy, No. (\%) & $12(12)$ & $7(13)$ & $5(10)$ & 0.76 \\
\hline Time between AKI and ICU admission (days), median [IQR] & $4[2-8]$ & $4[3-7]$ & $4[1-9]$ & 0.74 \\
\hline AKD, No. (\%) & $24(24)$ & $14(27)$ & $10(21)$ & 0.49 \\
\hline
\end{tabular}

Chronic respiratory disease includes chronic obstructive bronchopneumonia and asthma. The Kidney Disease: Improving Global Outcomes (KDIGO) definition was used to define AKI Stages 1,2 and 3. Serum creatinine $(\mathrm{SCr})$ and urine output were both taken into account. Continuous variables are reported as mean (standard deviation) or median [interquartile range] if the variable did not fit a normal distribution and categorical variables are reported as numbers (percentages). Quantitative variables were compared using a $t$-test, and qualitative variables were compared using Fisher's exact test

AKD, acute kidney disease; AKI, acute kidney injury; BMI, body mass index; CKD, chronic kidney disease; D28, day 28; KDIGO, Kidney Disease Improving Global Outcomes; ICU, intensive care unit; IQR, interquartile; SAPSII, Simplified Acute Physiology Score; SCr, serum creatinine; SD, standard deviation; RASi, renin-angiotensin system inhibitor 
Table 2 Univariate and multivariate analysis for AKI development

\begin{tabular}{|c|c|c|c|c|}
\hline & \multicolumn{2}{|c|}{ Univariate analysis } & \multicolumn{2}{|c|}{ Multivariate analysis } \\
\hline & OR (AKI) & $\mathrm{Cl} 95 \%$ & OR (AKI) & $\mathrm{Cl} 95 \%$ \\
\hline \multicolumn{5}{|l|}{ Baseline characteristics } \\
\hline Males, No. (\%) & 0.88 & {$[0.34-2.22]$} & & \\
\hline Age (years), mean (SD) & 1.006 & {$[0.97-1.04]$} & 1.02 & {$[0.97-1.07]$} \\
\hline BMI, mean (SD) & 1.05 & {$[0.98-1.14]$} & & \\
\hline CKD, No. (\%) & 3.50 & {$[0.82-24.05]$} & 4.10 & {$[0.71-33.79]$} \\
\hline Hypertension, No. (\%) & 2.31 & {$[1.03-5.29]$} & 1.93 & {$[0.66-5.78]$} \\
\hline Diabetes, No. (\%) & 0.76 & {$[0.33-1.77]$} & & \\
\hline Ischemic cardiopathy, №. (\%) & 1.91 & {$[0.58-7.50]$} & & \\
\hline Chronic respiratory disease, №. (\%) & 1.15 & {$[0.40-3.44]$} & & \\
\hline Immunosuppression, №. (\%) & 1.64 & {$[0.41-8.14]$} & & \\
\hline RASi exposure, No. (\%) & 1.54 & {$[0.67-3.64]$} & & \\
\hline Time between first symptoms and ICU admission (days), mean (SD) & 0.97 & {$[0.87-1.07]$} & & \\
\hline \multicolumn{5}{|l|}{ In the first $24 \mathrm{~h}$ of ICU hospitalization (before AKI development) } \\
\hline SAPS II, median [IQR] & 1.04 & {$[1.01-1.07]$} & & \\
\hline Catecholamine use, No. (\%) & 3 & {$[0.68-20.87]$} & & \\
\hline Mechanical ventilation, №. (\%) & 8.92 & {$[3.65-23.66]$} & 5.02 & {$[1.68-15.78]$} \\
\hline Worst $\mathrm{PaO}_{2} / \mathrm{FiO}_{2}$ ratio, median [IQR] & 0.99 & {$[0.98-1]$} & & \\
\hline Intravenous fluid therapy $(\mathrm{L})$, median [IQR] & 1.67 & {$[1.20-2.47]$} & 1.35 & {$[0.90-2.14]$} \\
\hline Dexamethasone use, No. (\%) & 0.18 & {$[0.07-0.42]$} & 0.31 & {$[0.09-0.99]$} \\
\hline
\end{tabular}

Univariate and multivariate analysis was proceeded using logistic regression. To choose independent variables included in the multivariate model, we allowed one independent variable for every 10 dependent variable's outcomes analyzed. Independent variables with a $p$-value $<0.20$ in the univariate analysis were taken into consideration, and we kept variables which were previously described to be associated with AKI or highly associated $(p<0.05)$ with AKI in the univariate analysis. Absence of collinearity was checked

AKI, acute kidney injury; BMI, body mass index; CKD, chronic kidney disease; ICU, intensive care unit; IQR, interquartile; SAPSII, Simplified Acute Physiology Score; SD, standard deviation; RASi, renin-angiotensin system inhibitor

Our study suggests an independent effect of DXM to prevent from AKI in severe COVID-19 patients. This result needs to be confirmed in larger studies.

High rate of vasopressors and greater intravenous fluid therapy reported during the first wave imaged the earlier and more frequent use of MV, without reflecting the patients' severity admitted in our ICU. Indeed, patients admitted during the second wave had more comorbidities and were older, which explains the increased mortality trend observed in our study.

Lack of effect of DXM on RRT in our study can be explained by a lack of power and by the too weak effect of corticosteroids on AKI.

Our results could indicate an important impact of inflammatory state in the pathogenesis of COVID-19-induced AKI. These results support the hypothesis that corticosteroid therapy can reduce "inflammatory" AKI incidence (specific of COVID-19 infection) but has no impact on "maladaptive repair" lesions secondary to AKI that can lead to an AKD.

Acknowledgements

We thank all doctors and residents who took care of the patients.

\section{Authors' contributions}

$A O, S R$ and $A B$ conceived and designed the study, analyzed the data and drafted the manuscript. AO was responsible for data acquisition. PK, RP and DG helped to conduct the study. All authors read and approved the final manuscript.

\section{Funding}

No funding.

\section{Availability of data and materials}

The dataset used and analyzed for the current study is available from the corresponding author on reasonable request.

\section{Declarations}

\section{Ethics approval and consent to participate}

Patients data were routinely collected in dedicated electronic health records during their entire hospital stay. According to French law and the French Data Protection Authority, the handling of these data for research purposes was declared to the Data Protection Officer of the University Hospital of Bordeaux. Patients (or their relatives, if any) were notified about the anonymized use of their health care data via the department's booklet.

\section{Consent for publications}

Not applicable.

\section{Competing interests}

The authors declare that they have no competing interests. 


\section{Author details}

'Service de Médecine Intensive Réanimation, Hôpital Pellegrin, Place Amélie Raba Léon, CHU de Bordeaux, 33000 Bordeaux, France. ${ }^{2}$ Unité INSERM U1045, Université de Bordeaux, Bordeaux, France. ${ }^{3}$ Service de Néphrologie, Transplantation, Dialyse, Aphérèses, Hôpital Pellegrin, CHU de Bordeaux, Bordeaux France. ${ }^{4}$ Unité INSERM U1034, Université de Bordeaux, Bordeaux, France.

Received: 13 March 2021 Accepted: 3 July 2021

Published online: 16 July 2021

\section{References}

1. Contou D, et al. Comparison between first and second wave among critically ill COVID-19 patients admitted to a French ICU: no prognostic improvement during the second wave? Crit Care. 2021;25:3.

2. The RECOVERY Collaborative Group. Dexamethasone in Hospitalized Patients with Covid-19. N Engl J Med. 2021:384:693-704.
3. Rubin S, et al. Characterization of acute kidney injury in critically ill patients with severe coronavirus disease 2019. Clin Kidney J. 2020. https://doi.org/10.1093/ckj/sfaa099.

4. Gabarre P, et al. Acute kidney injury in critically ill patients with COVID-19. Intensive Care Med. 2020:46:1339-48.

5. Nadim MK, et al. COVID-19-associated acute kidney injury: consensus report of the 25th Acute Disease Quality Initiative (ADQI) Workgroup. Nat Rev Nephrol. 2020. https://doi.org/10.1038/s41581-020-00356-5.

6. Orieux A, et al. Severe COVID-19 induced AKI: a 3-month follow-up. Clin Kidney J. 2021. https://doi.org/10.1093/ckj/sfab028.

\section{Publisher's Note}

Springer Nature remains neutral with regard to jurisdictional claims in published maps and institutional affiliations.
Ready to submit your research? Choose BMC and benefit from:

- fast, convenient online submission

- thorough peer review by experienced researchers in your field

- rapid publication on acceptance

- support for research data, including large and complex data types

- gold Open Access which fosters wider collaboration and increased citations

- maximum visibility for your research: over $100 \mathrm{M}$ website views per year

At BMC, research is always in progress.

Learn more biomedcentral.com/submissions 